\title{
Chapter 4 \\ Rhizosphere Processes and Root Traits Determining the Acquisition of Soil Potassium
}

\author{
Philippe Hinsinger, Michael J. Bell, John L. Kovar, and Philip J. White
}

\begin{abstract}
Plants acquire $\mathrm{K}^{+}$ions from the soil solution, and this small and dynamic pool needs to be quickly replenished via desorption of surface-adsorbed $\mathrm{K}$ from clay minerals and organic matter, by release of interlayer $\mathrm{K}$ from micaceous clay minerals and micas, or structural $\mathrm{K}$ from feldspars. Because of these chemical interactions with soil solid phases, solution $\mathrm{K}^{+}$concentration is kept low and its mobility is restricted. In response, plants have evolved efficient strategies of root foraging. Root traits related to root system architecture (root angle and branching), root length and growth, together with root hairs and mycorrhiza-related traits help to determine the capacity of plants to cope with the poor mobility of soil K. Rooting depth is also important, given the potentially significant contribution of subsoil $\mathrm{K}$ in many soils. Root-induced depletion of $\mathrm{K}^{+}$shifts the exchange equilibria, enhancing desorption of $\mathrm{K}$, as well as the release of nonexchangeable, interlayer $\mathrm{K}$ from minerals in the rhizosphere. Both these pools can be bioavailable if plant roots can take up significant amounts of $\mathrm{K}$ at low concentrations in the soil solution (in the micromolar range). In addition, roots can significantly acidify their environment or release large amounts of organic compounds (exudates). These two processes ultimately promote the dissolution of micas and feldspars in the rhizosphere, contributing to the mining strategy evolved by plants. There are thus several root or rhizosphere-related traits
\end{abstract}

\footnotetext{
P. Hinsinger $(\bowtie)$

Eco\&Sols, University of Montpellier, CIRAD, INRAE, Institut Agro, IRD, Montpellier, France e-mail: philippe.hinsinger@inrae.fr
}

\section{J. Bell}

School of Agriculture and Food Science, The University of Queensland, Brisbane, Australia e-mail: m.bell4@uq.edu.au

\section{J. L. Kovar}

USDA-ARS, National Laboratory for Agriculture and the Environment, Ames, IA, USA

e-mail: john.kovar@usda.gov

P. J. White

Ecological Sciences, The James Hutton Institute, Dundee, UK

King Saud University, Riyadh, Saudi Arabia

e-mail: philip.white@hutton.ac.uk 
(morphological, physiological, or biochemical) that determine the acquisition of $\mathrm{K}$ by crop species and genotypes.

\subsection{Soil Properties and Processes Determining the Acquisition of Potassium by Plants}

A number of soil characteristics determine $\mathrm{K}$ mobility, ${ }^{1}$ availability, and bioavailability to plants. These properties, together with the actual distribution of the various pools of $\mathrm{K}$ in the soil profile and horizons, ultimately determine the most desirable root and rhizosphere-related traits to search for in order to improve $\mathrm{K}$ acquisition efficiency in crops.

\subsubsection{Potassium Mobility: Mass Flow Versus Diffusion in the Rhizosphere}

Potassium is present in the soil solution as $\mathrm{K}^{+}$ions, which experience rather strong interactions (adsorption/desorption) with the many soil constituents contributing to cation exchange capacity, notably clay minerals and organic matter (Sparks and Huang 1985; Sparks 1987; Chap. 7). The consequences of such interactions are twofold. First, they buffer the concentration of $\mathrm{K}^{+}$in the soil solution to values that commonly range from one to several hundred micromoles per $\mathrm{dm}^{3}$ (Asher and Ozanne 1967; Hinsinger 2006), i.e., concentrations that are significantly greater than those of phosphate, but less than those of nitrate. Second, they limit K mobility in the soil. Thus, compared with nitrate, $\mathrm{K}$ leaching occurs in significant amounts only in fertilized, light-textured soils. In addition, while mass flow can contribute significantly to the transport of nitrate toward the root surface as a consequence of transpiration-driven water uptake and corresponding solute movement, its contribution to the supply of $\mathrm{K}^{+}$and phosphate ions is small (Barber 1995). Hence most $\mathrm{K}^{+}$is transported to the root surface by diffusion, as a consequence of the concentration gradients that develop in the rhizosphere (Tinker and Nye 2000; Jungk 2001, 2002). Barber (1995) estimated that diffusion contributed about $80 \%$ of the K delivered to maize (Zea mays L.) roots in a Chalmers silt loam (Mollisol) soil (Table 4.1).

\footnotetext{
${ }^{1}$ Mobility is used here to describe the ability of $\mathrm{K}^{+}$ions to move in soils, either vertically through leaching or laterally, through mass flow and diffusion (e.g., Hinsinger 2004).
} 
Table 4.1 Estimated contributions of diffusion and mass flow to the acquisition of major nutrient ions in maize grown in field conditions in a Chalmers silt loam (Mollisol) soil and yielding $9500 \mathrm{~kg}$ grain $\mathrm{ha}^{-1}$. (adapted from Barber 1995)

\begin{tabular}{l|l|l|l}
\hline Nutrient ion & Diffusion & Mass flow & Acquisition \\
\hline & $\mathrm{kg} \mathrm{ha}^{-1}$ & $\mathrm{~kg} \mathrm{ha}^{-1}$ & $\mathrm{~kg} \mathrm{ha}^{-1}$ \\
\hline Potassium & 156 & 35 & 195 \\
\hline Phosphate & 37 & 2 & 40 \\
\hline Nitrate & 38 & 150 & 190 \\
\hline
\end{tabular}

\subsubsection{Potassium Availability and Bioavailability: Exchangeable Versus Nonexchangeable Pools in the Rhizosphere}

The availability of a nutrient is an intrinsic property of the soil that is usually assessed by chemical methods designed to extract the fraction of the nutrient that is likely to replenish the soil solution in response to depletion by nutrient uptake (Harmsen et al. 2005; Harmsen 2007). While it is usually expressed as a concentration, the bioavailability is best defined as the actual flux of a nutrient into a living organism (Harmsen et al. 2005; Harmsen 2007), which means that it varies for a given soil, nutrient, and set of environmental conditions, as well as the organism of interest (e.g., the plant species or genotype). This is due to both differences in uptake capacities and abilities to alter the availability in the bio-influenced zone (Harmsen et al. 2005), which corresponds to the rhizosphere for plants (Hinsinger et al. 2011). For K, it was long assumed that the only bioavailable pools were $\mathrm{K}^{+}$ions in the soil solution and surface-adsorbed $\mathrm{K}$, i.e., $\mathrm{K}^{+}$ions adsorbed onto negatively charged soil constituents (Sparks and Huang 1985; Sparks 1987), which are often assessed via an extraction with ammonium salts. These correspond to the so-called exchangeable $\mathrm{K}$ pool that represents typically about $1-2 \%$ of total soil K (Chap. 7). It has been well documented that plants can exploit this pool, which is therefore bioavailable.

Most soil $\mathrm{K}$ is, however, nonexchangeable in the sense that it cannot be extracted by an ammonium salt. There are two main nonexchangeable pools, corresponding to either $\mathrm{K}^{+}$contained in the interlayers of micas, partially weathered micas and secondary layer silicates (Chap. 7, Fig. 7.1, pools 10 and 11) or in the structure of other K-bearing silicates (Chap. 7, Fig. 7.1, pool 12), feldspars being the most abundant ones (Sparks and Huang 1985; Sparks 1987; Chap. 7). These have been referred to as interlayer $\mathrm{K}$ and structural $\mathrm{K}$, respectively, and were thought to be poorly or not bioavailable. However, there is growing evidence that the $\mathrm{K}$ in these pools is bioavailable to some plants, as further explained below (Hinsinger 2006, 2013). 


\subsubsection{Soil Profile Distribution: Topsoil Versus Subsoil Potassium Availability and Bioavailability}

It is often observed that the topsoil is enriched in nutrients compared to the subsoil, or at least exhibits greater nutrient availability. This occurs in many natural ecosystems due to the role of vegetation in the rapid recycling of nutrients through uptake and litterfall as well as throughfall, the latter being especially important for K. Nutrients accumulate in the topsoil, and whenever uptake occurs at greater depth, from subsoil layers, this ultimately contributes to nutrient accumulation in the topsoil (Jobbagy and Jackson 2001). In agroecosystems, the topsoil can also be enriched by K fertilization (Obrycki et al. 2018), but there is also some evidence for significant uptake of $\mathrm{K}$ occurring from the subsoil with redistribution to the soil surface in residues (Barré et al. 2009). This overlooked component of the soil, namely the subsoil and the potential reservoir of bioavailable nutrients it can represent, has been reviewed by Kautz et al. (2013), who stressed the need to assess its contribution to plant nutrition further. Kuhlmann (1990) provided some quantitative assessment of the contribution of the subsoil to wheat (Triticum aestivum L.) K nutrition, which ranged from 7 to $70 \%$, with an average of 34\% in Luvisols of Northern Germany. The contribution may be less in deeply weathered soils such as Oxisols and Ultisols, which contain less exchangeable and nonexchangeable $\mathrm{K}$ stocks. However, for deep-rooted plants such as eucalypt (Eucalyptus grandis) in deep Oxisols in Brazil, it has been shown that significant root-soil interactions occur at considerable depths, affecting the fate of $\mathrm{K}$ to at least $4 \mathrm{~m}$ (Pradier et al. 2017). This reinforces the need to take subsoil $\mathrm{K}$ into consideration in future research and in K-fertilizer recommendations, as well as when designing more K-efficient ideotypes of crops in breeding programs (Thorup-Kristensen et al. 2020).

\subsection{Root Morphological Traits Determining the Acquisition of Potassium by Plants}

Because of the restricted mobility of various nutrient ions, including $\mathrm{K}^{+}$, ammonium, and phosphate in soils, plants have evolved a range of foraging strategies in order to increase the volume of their rhizosphere, i.e., the actual volume of soil from which they can acquire these poorly mobile nutrients (Hinsinger 2004; Lynch 2007; Hinsinger et al. 2011).

\subsubsection{Root System Architecture and Plasticity}

Plant species can differ considerably in root system architecture (RSA), with the tap-rooted systems and fibrous systems found in crops being good examples 
(Kutschera et al. 2009). Tap-rooted systems usually enable plants to access deeper horizons, while colonizing the topsoil less densely than fibrous systems. Witter and Johansson (2001) compared forage species and estimated that the tap- and deeprooted alfalfa (Medicago sativa $\mathrm{L}$.) obtained about $67 \%$ of its $\mathrm{K}$ from the subsoil, while ryegrass (Lolium spp.), with its fibrous root system, obtained only $42 \%$ of its K from the subsoil under the same conditions. While the type of RSA (e.g., tap-rooted vs. fibrous) is genetically determined, it has been shown that there is considerable variation in RSA within a given species, which is a promising avenue for selecting more efficient crop genotypes of a broad range of species (Lynch 2007, 2015; Hammond et al. 2009; White et al. 2013; Mi et al. 2016; Thomas et al. 2016; Jin et al. 2017). While most of the work done so far has focused on $\mathrm{N}$ or phosphorus (P), some of these results could be easily extended to K. The root angle and distance between lateral roots are traits that will largely determine inter-root competition and the overlapping of the rhizosphere of neighboring roots, which is of greater concern for mobile resources, such as water and nitrate, than for poorly mobile nutrients, such as $\mathrm{K}$ or $\mathrm{P}$ (Ge et al. 2000).

Lynch and co-workers have shown in common bean (Phaseolus vulgaris L.) and maize that shallow-rooted genotypes may perform better than deep-rooted genotypes whenever there is a strong vertical gradient of fertility, with much greater nutrient availability in the topsoil than in the subsoil (Ge et al. 2000) and that past breeding schemes have resulted in selecting more shallow root systems in maize in the USA (York et al. 2015). Conversely, in soils exhibiting significant resources of $\mathrm{K}$ at depth, which is common in temperate conditions and even more so when accounting for nonexchangeable $\mathrm{K}$ pools, crop species that invest in deeper roots may derive more $\mathrm{K}$ from the subsoil, as shown by Kuhlmann (1990) in a loess soil in Germany (Fig. 4.1). The work of York et al. (2015) has also shown considerable plasticity of RSA traits, some of which vary substantially with sowing density, for instance. Such plasticity is an intrinsic property of root systems, which further complicates their study and phenotyping, but which plays a major role in the adaptive strategy of plants to acquire mineral nutrients. In contrast to nitrogen $(\mathrm{N})$ and $\mathrm{P}$, plants do not seem to respond to K-rich patches by enhanced root proliferation (Drew 1975; Hermans et al. 2006), which may restrict the options for effective fertilizer $\mathrm{K}$ placement, unless co-located with $\mathrm{N}$ or P. Nevertheless, we would argue that there is considerable progress to be expected from integrating RSA-related traits into breeding programs, and this is urgently needed to obtain genotypes that can better cope with spatially restricted availability of nutrients such as N, P, or K (Lynch 2015; Thorup-Kristensen et al. 2020).

\subsubsection{Root Length and Growth}

For poorly mobile nutrients, it has long been known that root length or root surface area is among the most relevant traits determining their acquisition (Barber 1995). In their sensitivity analysis, Silberbush and Barber (1983) showed that the predicted K 


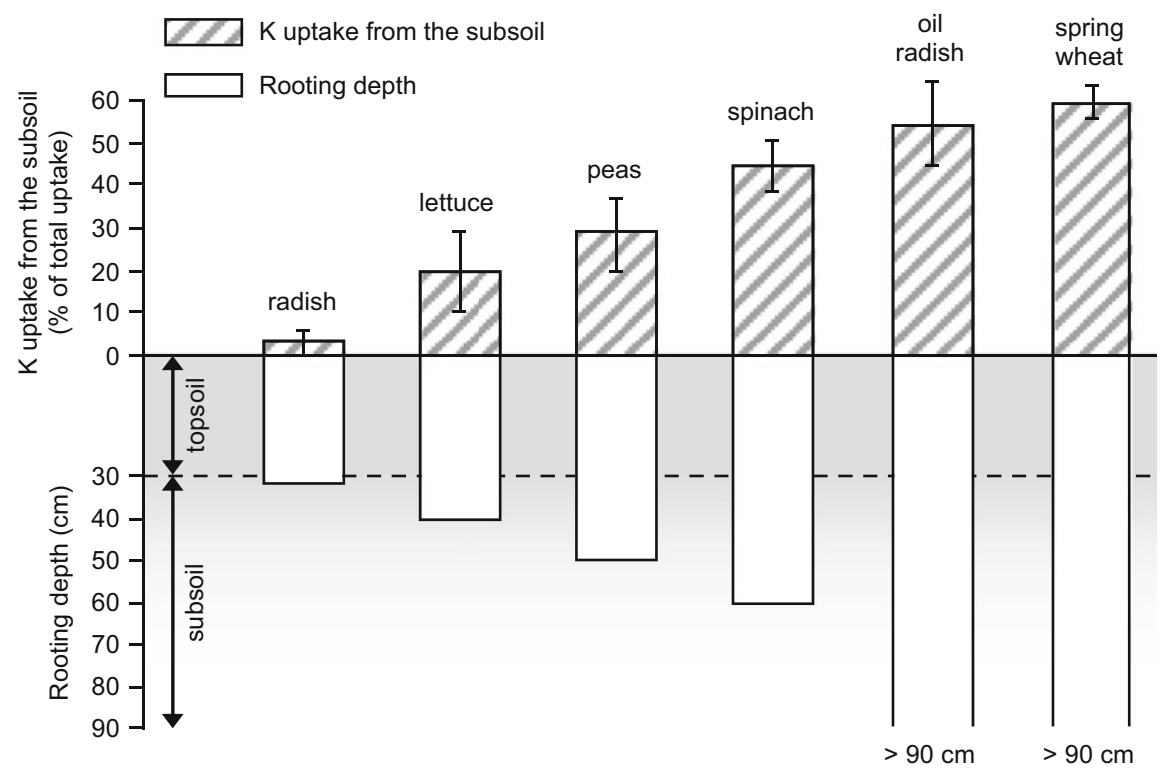

Fig. 4.1 Relative contribution of the subsoil to $\mathrm{K}$ acquisition as a function of rooting depth of different crop species grown in field conditions in a loess-derived, deep soil (Cambisol) with topsoil containing $90 \mathrm{mg} \mathrm{kg}^{-1}$ exchangeable $\mathrm{K}$ and subsoil containing $160 \mathrm{mg} \mathrm{kg}^{-1}$ exchangeable K. Deep-rooted crops such as oil radish (Raphanus sativus L.) and spring wheat acquired more than $50 \%$ of their K from the subsoil. (adapted from Kuhlmann 1990)

acquisition by soybean was increased more by an increase in root surface area than by the same relative increase in any other parameter in the classic Barber-Cushman model. More recently, Wissuwa (2003) predicted that a $22 \%$ increase in the root surface area of rice (Oryza sativa L.) was enough to give a threefold increase in $\mathrm{P}$ acquisition under P-limiting conditions. Given that the mobility of $\mathrm{K}^{+}$is greater than that of phosphate in soils, it is likely that an even smaller change of root surface area would have a significant impact on $\mathrm{K}$ acquisition. In this respect, the modelling work by Pagès (2011), conducted with a more realistic distribution of roots based on RSA, rather than an evenly distributed root system as in the Barber-Cushman-derived models, revealed that greater root length was ecologically relevant for the acquisition of poorly mobile nutrients, such as $\mathrm{P}$, but not for mobile ions, such as nitrate (due to large overlapping of nitrate depletion zones). The results for $\mathrm{K}^{+}$and ammonium ions were intermediate.

Genotypes within a species can exhibit considerable variation in root length, as has been shown for potato (Wishart et al. 2013) and maize (Erel et al. 2017). While the relationship between crop performance (growth or yield) under nutrient-limiting conditions and root length was not consistently significant or positive, these studies suggest that the impact of root length variation is worthy of more detailed investigation. While root length was weakly correlated with $\mathrm{K}$ uptake in a range of lentil (Lens culinaris Medik) genotypes, Gahoonia et al. (2006) showed that root hair 
length was an even more relevant root trait for poorly mobile nutrients such as $\mathrm{K}$ or P. As for RSA, root length and related traits such as specific root length or root surface area are not just genetically determined, but are also highly plastic, responding to many environmental factors and biological stimuli. Plant growthpromoting microorganisms are an example of the latter, with some of these directly altering root growth or proliferation (Vacheron et al. 2013).

\subsubsection{Root Hairs and Mycorrhizae}

It has been well documented for the least mobile nutrients, such as $\mathrm{P}$, that morphological or anatomical features other than RSA and root length-related traits can play a major role in extending the rhizosphere volume, and hence the actual amounts of nutrients acquired. These include root hairs that can extend up to several millimeters from the root surface (e.g., Gahoonia et al. 1997), and mycorrhizal hyphae which can access even greater volumes, extending up to several centimeters away from the root surface (e.g., Jakobsen et al. 1992; Thonar et al. 2011). Their direct implication for the acquisition of $\mathrm{K}^{+}$is less well documented than for $\mathrm{P}$, but there are a number of reports on the potential role of root hairs and mycorrhiza-related traits for improving the foraging capacity of plants for soil K. In their modelling of K uptake, Samal et al. (2010) showed that, assuming root hair surface areas ranging from 0.38 to $0.47 \mathrm{~cm}^{2} \mathrm{~cm}^{-2}$ root, root hairs contributed slightly less to $\mathrm{K}$ uptake than the roots alone (without their root hairs) in wheat and maize, but more than the roots alone in sugar beet (Beta vulgaris $\mathrm{L}$.). The significant role of root hairs in $\mathrm{K}$ acquisition is also supported by the strong correlation between root hair length and $\mathrm{K}$ acquisition found among crop species in decreasing order of efficiency (Fig. 4.2): oilseed rape (Brassica napus oliefera L.), tomato (Solanum lycopersicum Mill.), ryegrass, maize, onion (Allium spp.) (Claassen and Jungk 1984; Jungk 2001) or rye (Secale cerale L.), ryegrass (Lolium perenne), oilseed rape, alfalfa, barley (Hordeum vulgare), pea (Pisum sativum L.), and red clover (Trifolium pretense L.) (Høgh-Jensen and Pedersen 2003). Høgh-Jensen and Pedersen (2003) also reported some plasticity for this trait, as root hairs exhibited greater length at lower K supply, suggesting that investment in the length of root hairs is an adaptive strategy for improving $\mathrm{K}$ acquisition. Mycorrhizal hyphae can access a much greater volume of soil than roots, and thereby increase the effective radius of the rhizosphere. While their quantitative impact on $\mathrm{K}$ acquisition has been studied much less than for $\mathrm{P}$ acquisition, the K uptake transport systems involved in the mycorrhizal symbiosis are now well documented (Garcia and Zimmermann 2014). Additional research is needed on the functional side of this symbiosis before identifying relevant traits worthy of being pursued for improving $\mathrm{K}$ acquisition efficiency. 
Fig. 4.2 Relationship between $\mathrm{K}$ acquisition (K uptake rate) and the volume of the root hair cylinder in a range of crops. (adapted from Claassen and Jungk 1984)

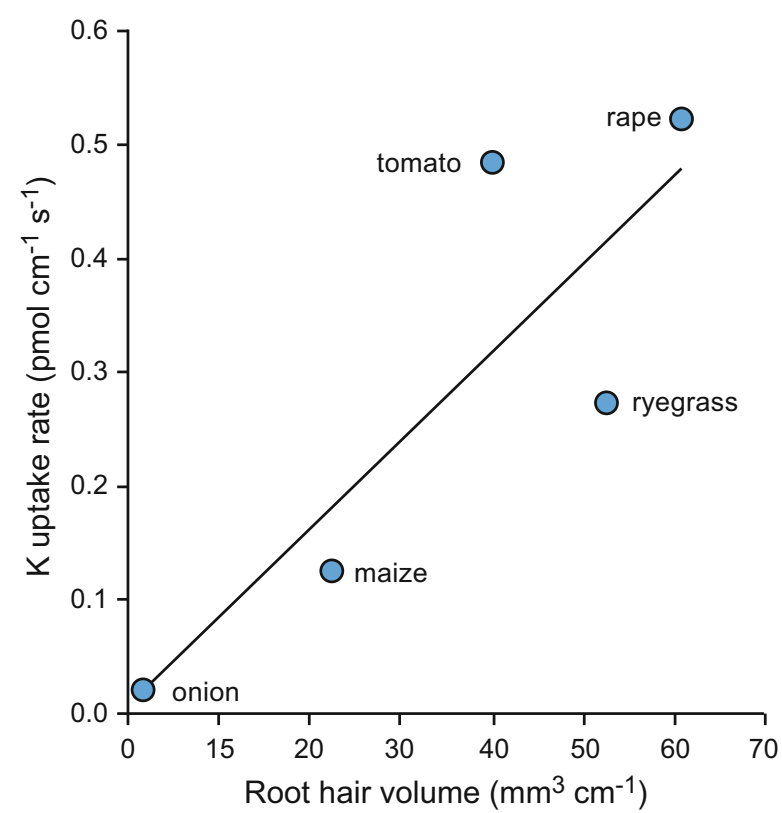

\subsection{Root Physiological Traits Determining the Acquisition of Potassium by Plants}

As potassium is present only as $\mathrm{K}^{+}$ions in soils, which interact strongly with negatively charged soil constituents or are part of the crystal structures of silicate minerals, $\mathrm{K}$ acquisition by plants is dependent on the mobilization of $\mathrm{K}$ from these sources. Depletion of $\mathrm{K}^{+}$in the rhizosphere soil solution and the excretion of protons and other K-mobilizing exudates (a so-called "mining" strategy) can increase the availability of poorly available forms of soil $\mathrm{K}$ in the vicinity of roots and contribute to improved plant nutrition (Hinsinger et al. 2011).

\subsubsection{Traits Related to Potassium Uptake and Depletion in the Rhizosphere}

For poorly mobile nutrients such as $\mathrm{P}$ or $\mathrm{K}$, the uptake capacity of root cells, determined by the rate of transport of ions across the plasma membrane, is not the limiting step for their acquisition. This contrasts markedly with the situation for more mobile nutrients, such as nitrate, as confirmed by sensitivity analysis of BarberCushman and other plant nutrition models (Rengel 1993). Nevertheless, in the case of $\mathrm{K}$, the uptake of $\mathrm{K}^{+}$is a driving process for accessing both the exchangeable pool and even a significant part of the nonexchangeable pool (Hinsinger 2006; Hinsinger 
Fig. 4.3 Depletion of ${ }^{86} \mathrm{Rb}$ in the rhizosphere of 13-day-old maize roots, as revealed by autoradiography, using radioactive $\mathrm{Rb}$ as a proxy for $\mathrm{K}$. The white areas around roots correspond to depletion zones, while the black areas correspond to zones of ${ }^{86} \mathrm{Rb}$ accumulation inside the roots, especially the root apices, where the uptake presumably occurs at a higher flux. (adapted from Walker and Barber 1962)
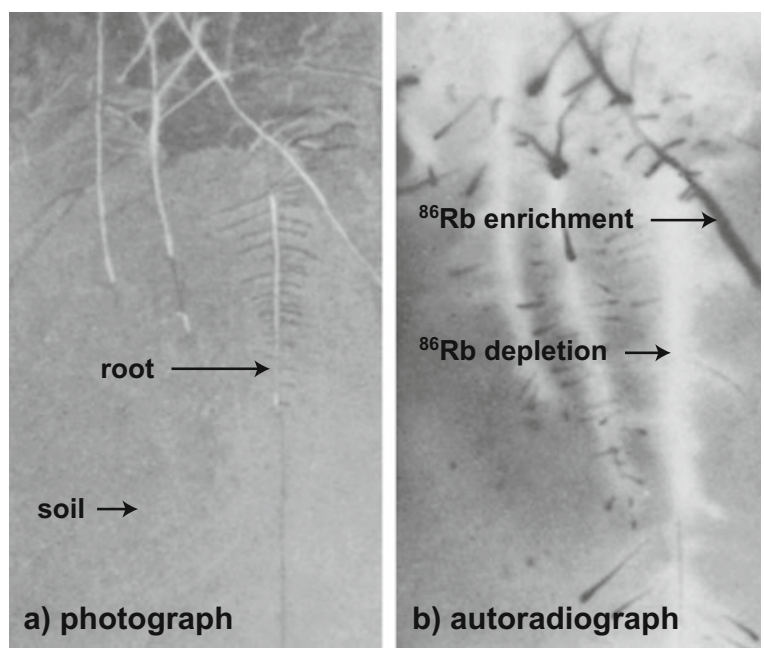

et al. 2011; White et al. 2013), namely interlayer K from micas and micaceous clay minerals (Chap. 7, Fig. 7.1, pools 10 and 11). When roots take up $\mathrm{K}^{+}$from the soil solution, a rapid depletion of $\mathrm{K}^{+}$occurs in the rhizosphere. This was first observed in the early 1960s using autoradiography of a radioactive analogue of $\mathrm{K},{ }^{86} \mathrm{Rb}$, which demonstrated the occurrence of a depletion zone extending a few millimeters from the surface of maize roots (Fig. 4.3) (Walker and Barber 1962), and was later confirmed by a range of approaches, based on direct measurements or modelling (e.g., Kuchenbuch and Jungk 1982; Claassen et al. 1986). The latter studies also demonstrated that $\mathrm{K}^{+}$uptake by roots can deplete the exchangeable pool of $\mathrm{K}$ by causing a shift in the cation exchange equilibria toward enhanced desorption of $\mathrm{K}^{+}$ ions from the surface-adsorbed K pool (Chap. 7, Fig. 7.1, pool 9).

As plant roots are capable of decreasing the concentration of $\mathrm{K}^{+}$from several hundreds of micromoles per $\mathrm{dm}^{-3}$ in the bulk soil down to concentrations in the micromolar range at the root surface (Fig. 4.4), they can even shift the equilibria determining the release of interlayer $\mathrm{K}$ in micaceous phyllosilicate minerals (e.g., micas, illite, illite interstratified with smectite and vermiculite, i.e., pools 10 and 11 in Fig. 7.1, Chap. 7), ultimately depleting the large pool of nonexchangeable $\mathrm{K}$ contained in soils (Kuchenbuch and Jungk 1982; Niebes et al. 1993; Moritsuka et al. 2004) and altering soil mineralogy (Kodama et al. 1994; Barré et al. 2007, 2008). This mechanism has been demonstrated to occur in the rhizosphere of ryegrass, using a phlogopite mica as the sole source of (almost exclusively interlayer) $\mathrm{K}$, which released significant amounts of interlayer $\mathrm{K}$ and was transformed into a vermiculite clay mineral within only a few days of growth (Hinsinger et al. 1992; Hinsinger and Jaillard 1993). Barré et al. (2007) further confirmed this alteration of soil mineralogy for illitic clay minerals in the rhizosphere of ryegrass in a pot experiment, and it was also shown in a field experiment with maize (Adamo et al. 2016). 
Fig. 4.4 Depletion of soil solution $\mathrm{K}$ in the rhizosphere of maize grown in two different soils exhibiting different $\mathrm{K}$ availabilities. (adapted from Claassen and Jungk 1982)

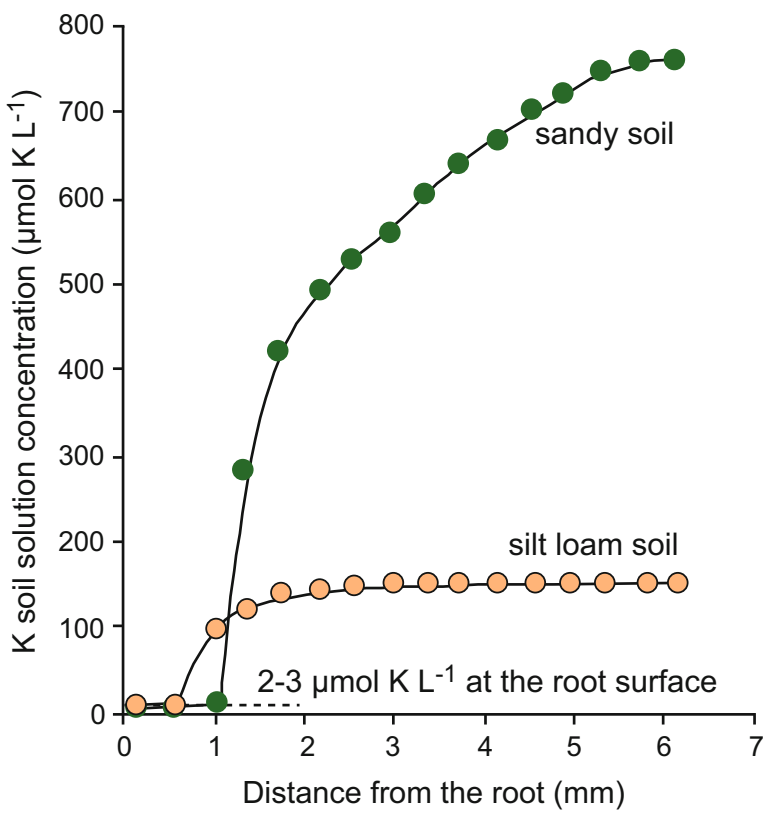

Springob and Richter (1998) have shown that the rate of release of nonexchangeable $\mathrm{K}$ in soils can be considerably enhanced below a threshold concentration of about 2-3 micromoles $\mathrm{K} \mathrm{dm}^{-3}$, which approximates the $\mathrm{K}$ concentration occurring close to the root surface as a consequence of $\mathrm{K}^{+}$uptake and subsequent depletion of $\mathrm{K}$ in the rhizosphere (Claassen and Jungk 1982; Hinsinger 2006). This steep decrease of $\mathrm{K}^{+}$concentration in the soil solution in the vicinity of roots thus drives the substantial and rapid depletion of exchangeable $\mathrm{K}$, but also the release of $\mathrm{K}$ from the nonexchangeable, interlayer pool (Fig. 4.5). The substantial release that can contribute from 20 up to 80 or $90 \%$ of the actual amount of $\mathrm{K}$ acquired by plants over rather short periods (a few days) shows that, in the peculiar conditions of the rhizosphere, and especially its low solution $\mathrm{K}^{+}$concentration (Fig. 4.6), the rates of this normally slow process can be much faster than expected (Claassen and Jungk 1982; Kuchenbuch and Jungk 1982; Hinsinger 2006; Niebes et al. 1993; Samal et al. 2010).

In this respect, the three important uptake characteristics that need to be considered are the $C_{\text {min }}$ value (minimal solution $\mathrm{K}$ concentration below which plants cannot take up $\mathrm{K}$ ) and the capacity to achieve a large $\mathrm{K}$ uptake rate at low $\mathrm{K}^{+}$ion concentrations, which depends on the $K_{\mathrm{m}}$ and $V_{\max }$ parameters of the MichaelisMenten equation. A low $C_{\min }$ value is achieved by coupling the proton gradient generated by a plasma membrane $\mathrm{H}^{+}$-ATPase to $\mathrm{K}^{+}$influx to root cells via a $\mathrm{H}^{+} / \mathrm{K}^{+}$ coupled symporter (White and Karley 2010; White 2013). This transporter has a low $K_{\mathrm{m}}$ for $\mathrm{K}^{+}$, and the required rate of $\mathrm{K}^{+}$influx is achieved by regulating its abundance and activity in response to plant K status (White and Karley 2010; White 2013). Plant species or genotypes showing very low $C_{\min }$ values (Asher and Ozanne 1967), 
Fig. 4.5 Relative contribution of exchangeable $\mathrm{K}$ to the actual $\mathrm{K}$ acquisition for different crops, showing significant contributions of nonexchangeable $\mathrm{K}$. (adapted from Samal et al. 2010)



and high affinity (low $\left.K_{\mathrm{m}}\right)$ and capacity $\left(V_{\max }\right)$ of their $\mathrm{K}$ transporters, would be better equipped for depleting $\mathrm{K}^{+}$ions to concentrations low enough to induce a significant release of interlayer $\mathrm{K}$ and thus access the large pool of nonexchangeable $\mathrm{K}$ that would be otherwise unavailable. Such K uptake traits differ among and within plant species, thus explaining differences in $\mathrm{K}$ bioavailability in a given soil, and might be worth considering for screening K-efficient crop genotypes (White 2013; White et al. 2016).

\subsubsection{Traits Related to $\mathrm{pH}$ Modification in the Rhizosphere}

It should be noted that a number of field experiments have reported an increase of some $\mathrm{K}$ pools in the rhizosphere, notably the exchangeable $\mathrm{K}$ pool, instead of depletion. This has been shown mostly in perennial tree species, e.g., by Courchesne and Gobran (1997) in a Norway spruce (Picea abies (L.) H. Karst.) forest, Bourbia et al. (2013) in an olive (Olea europaea L.) grove and Pradier et al. (2017) in a eucalypt (Eucalyptus grandis) plantation. These observations strongly suggest the occurrence of root-induced weathering processes, resulting in an increase of exchangeable $\mathrm{K}$ at the expense of the nonexchangeable $\mathrm{K}$ pool through processes other than those mentioned above. For instance, Pradier et al. (2017) showed that root-induced acidification of the rhizosphere of eucalypt trees may have partly contributed to the increase of exchangeable $\mathrm{K}$ that was observed in the rhizosphere throughout the soil profile to a depth of $4 \mathrm{~m}$. Plant roots can modify rhizosphere $\mathrm{pH}$ 


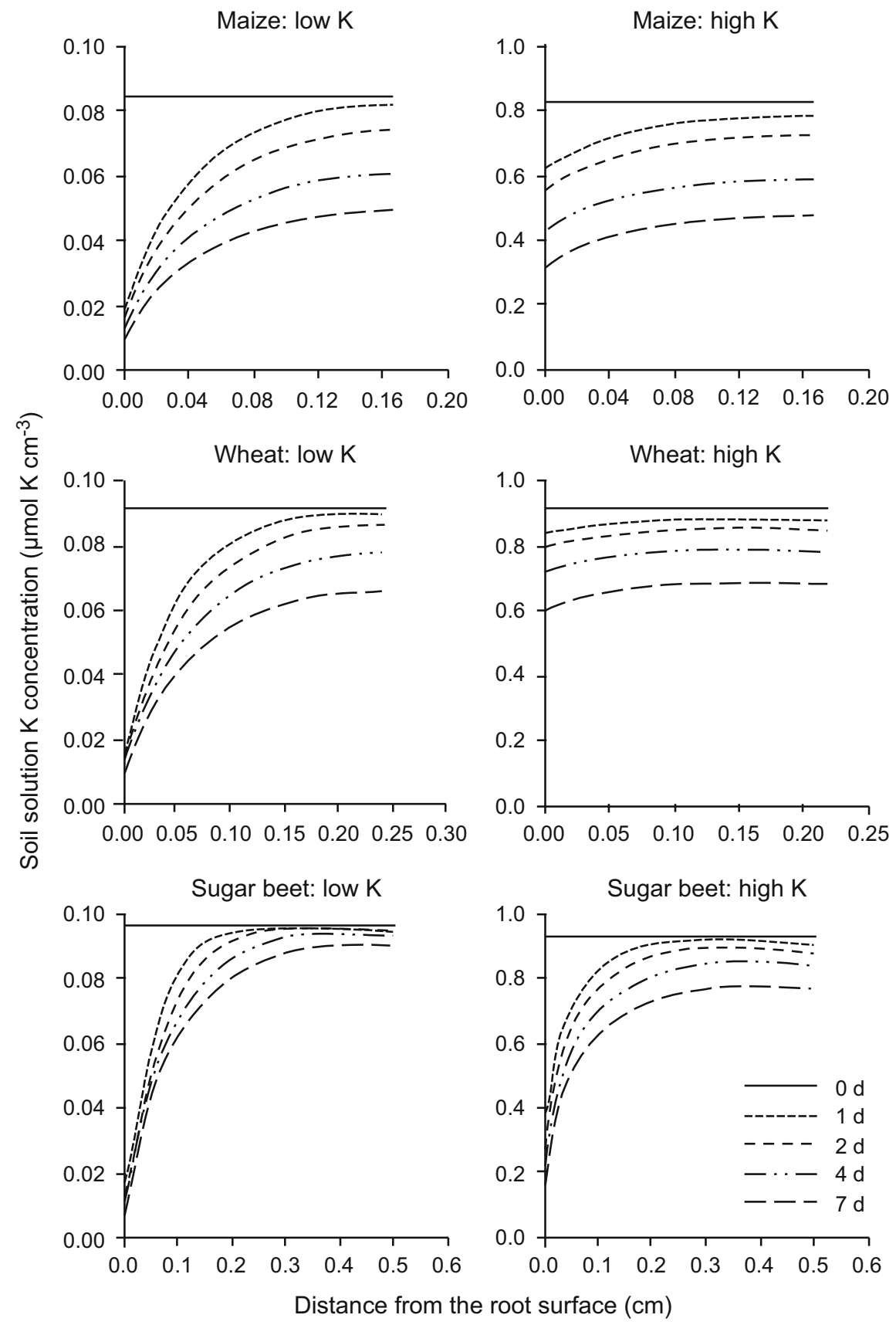

Fig. 4.6 Simulated depletion of $\mathrm{K}$ in the rhizosphere as a function of time for different crops. (adapted from Samal et al. 2010) 
considerably and root-mediated acidification of up to $2-3 \mathrm{pH}$ units has been observed repeatedly (e.g., Römheld 1986; Hinsinger et al. 2003; Blossfeld et al. 2013). Such a decrease in $\mathrm{pH}$ can have a dramatic effect on the weathering rate of minerals such as K-bearing silicates, through proton-promoted dissolution (Berner et al. 2003; Taylor et al. 2009; Hinsinger 2013).

The ability to modify rhizosphere $\mathrm{pH}$ varies among plant species. For instance, faba bean (Vicia faba L.) reduced rhizosphere $\mathrm{pH}$ more effectively than maize (Liu et al. 2016) and oilseed rape induced a dissolution of the phlogopite mica as a consequence of rhizosphere acidification, while ryegrass did not (Hinsinger et al. 1993). Such root-induced dissolution of K-bearing minerals has not been widely studied in crops to our knowledge, but a number of studies have been conducted in the context of forest trees. For example, Arocena et al. (1999) showed that the acidification occurring around ectomycorrhizas could be involved in the dissolution of micas and feldspars. The capacity of roots to change the rhizosphere $\mathrm{pH}$ is not a simple trait to target, however, as root-mediated $\mathrm{pH}$ changes are essentially the consequence of an imbalanced uptake of major cations and anions (Hinsinger et al. 2003). Rhizosphere acidification occurs when a net surplus of major cations $\left(\mathrm{K}^{+}\right.$being often predominant in the cation budget of plants) are taken up relative to the sum of major anions. Thus, there are many ways to increase rhizosphere acidification, and it is not expected to be related to a single trait, as the underlying mechanisms are largely determined by the environmental context. Nevertheless, plant species or genotypes could be screened quite easily for their capacity to acidify their rhizosphere in a given context (Gahoonia et al. 2006). This has been shown in common bean by Yan et al. (2004), who found significant heritability of a measured trait called total acid exudation, which was also able to account for a significant part of genotypic variation in $\mathrm{P}$ uptake.

\subsubsection{Traits Related to Exudates in the Rhizosphere}

Besides protons, roots can release large quantities of diverse exudates, including some that can also promote the dissolution of K-bearing silicates and thus the release of nonexchangeable K, i.e., interlayer or structural K (pools 10-11 or 12, Fig. 7.1, Chap. 7). Examples of these include carboxylates, such as citrate, oxalate, and malate, which are able to complex cations when they are released from the crystal structure of K-bearing minerals (Jones 1998). Such exudates can thus be involved in the dissolution of feldspars and micas (Razzaghe and Robert 1979; Robert and Berthelin 1986; Song and Huang 1988; Barman et al. 1992; Lawrence et al. 2014), and enhance the release of nonexchangeable K, i.e., structural or interlayer K, together with the other metal cations contained in these silicates. Screening wheat, maize, and sorghum (Sorghum bicolor (L.) Moench) genotypes for their release of malate and citrate to detoxify $\mathrm{Al}$ has been successful, which shows that such a trait can vary substantially within some plant species (e.g., Ryan et al. 2011). However, variation is certainly greater between species, with some crops such as white lupin 
(Lupinus albus L.) or chickpea (Cicer arietinum L.) being well known for their large carboxylate exudation capacity (Jones 1998). Even minute amounts of malate or citrate exuded at the root tip may provide sufficient protection against $\mathrm{Al}$ toxicity (Ryan et al. 2011), but much greater concentrations would be needed to induce significant release of $\mathrm{K}$ through such ligand-promoted dissolution of K-bearing silicates. There is no direct evidence to our knowledge that such exudation traits are worth pursuing for improving $\mathrm{K}$ acquisition efficiency in crops.

In addition to the exudation of such ligands, a considerable range and amount of other C-compounds can be released by roots (Jones 1998; Jones et al. 2009). Exudation is thus an important but complex process occurring in the rhizosphere, which stimulates the microbial communities and has potential implications for the dissolution of nutrient-bearing minerals (e.g., Philippot et al. 2013), as reviewed for fungi by Hoffland et al. (2004).

\subsection{Summary and Conclusions}

A number of root or rhizosphere-related traits determine the K acquisition efficiency of crops, influencing both their foraging and mining strategies. To deal with the restricted mobility of $\mathrm{K}^{+}$ions in soils, the foraging strategy of plants is based on a number of root traits, including densely branched root system architectures with substantial portions exploring the topsoil and the subsoil, with a large root surface area or length. In addition, roots can expand the volume of exploited soil and K-depletion zones considerably by developing long root hairs or supporting strong mycorrhizal symbioses and extensive hyphal networks.

In addition to this foraging strategy, which enlarges the volume of the rhizosphere, plants have also evolved various mining strategies to increase the bioavailability of all the $\mathrm{K}$ pools in the rhizosphere. The corresponding traits are related first to the ability of roots to sustain high fluxes of $\mathrm{K}$ at very low concentrations in the soil solution. This induces a shift in the exchange equilibria and an enhanced desorption of exchangeable $\mathrm{K}$ (surface-adsorbed $\mathrm{K}$ from clay minerals and organic matter), as well as an enhanced release of nonexchangeable, interlayer $\mathrm{K}$ contained in micaceous minerals. Second, roots can promote the dissolution of K-bearing silicates such as micas and feldspars through rhizosphere acidification and/or exudation of complexing ligands, such as some carboxylates. How to make better use of these traits in the context of a sustainable intensification of agroecosystems is not obvious though, and breeders have not yet fully integrated belowground traits in their breeding schemes. To do so may introduce additional challenges, such as potential trade-offs with those traits required for the acquisition of other belowground resources (e.g., water, N, P, and micronutrients). 


\section{References}

Adamo P, Barré P, Cozzolino V, Di Meo V, Velde B (2016) Short term clay mineral release and re-capture of potassium in a Zea mays field experiment. Geoderma 264:54-60. https://doi.org/ 10.1016/j.geoderma.2015.10.005

Arocena JM, Glowa KR, Massicotte HB, Lavkulich L (1999) Chemical and mineral composition of ectomycorrhizosphere soils of subalpine fir (Abies lasiocarpa (Hook.) Nutt.) in the Ae horizon of a Luvisol. Can J Soil Sci 79(1):25-35. https://doi.org/10.4141/S98-037

Asher CJ, Ozanne PG (1967) Growth and potassium content of plants in solution cultures maintained at constant potassium concentrations. Soil Sci 103:155-161. https://doi.org/10. 1097/00010694-196703000-00002

Barber SA (1995) Soil nutrient bioavailability: a mechanistic approach, 2nd edn. Wiley, New York

Barman AK, Varadachari C, Ghosh K (1992) Weathering of silicate minerals by organic acids. I. Nature of cation solubilisation. Geoderma 53:45-63. https://doi.org/10.1016/00167061(92)90020-8

Barré P, Velde B, Catel N, Abbadie L (2007) Soil-plant potassium transfer: impact of plant activity on clay minerals as seen from X-ray diffraction. Plant Soil 292:137-146. https://doi.org/10. 1007/s11104-007-9208-6

Barré P, Montagnier C, Chenu C, Abbadie L, Velde B (2008) Clay minerals as a soil potassium reservoir: observation and quantification through X-ray diffraction. Plant Soil 302:213-220. https://doi.org/10.1007/s11104-007-9471-6

Barré P, Berger G, Velde B (2009) How element translocation by plants may stabilize illitic clays in the surface of temperate soils. Geoderma 151:22-30. https://doi.org/10.1016/j.geoderma.2009. 03.004

Berner EK, Berner RA, Moulton KL (2003) Plants and mineral weathering: present and past. In: Holland HD, Turekian KK (eds) Treatise on geochemistry, vol 5, pp 169-188. https://doi.org/ 10.1016/B0-08-043751-6/05175-6

Blossfeld S, Schreiber CM, Liebsch G, Kühn AJ, Hinsinger P (2013) Quantitative imaging of rhizosphere $\mathrm{pH}$ and $\mathrm{CO}_{2}$ dynamics with planar optodes. Ann Bot 112:267-276. https://doi.org/ 10.1093/aob/mct047

Bourbia SM, Barré P, Kaci MBN, Derridj A, Velde B (2013) Potassium status in bulk and rhizospheric soils of olive groves in North Algeria. Geoderma 197:161-168. https://doi.org/ 10.1016/j.geoderma.2013.01.007

Claassen N, Jungk A (1982) Kaliumdynamik im wurzelnahen Boden in Beziehung zur Kaliumaufnahme von Maispflanzen. Z Pflanzenernähr Bodenkd 145:513-525

Claassen N, Jungk A (1984) Bedeutung von Kaliumaufnahmerate, Wurzelwachstum und Wurzelhaaren für das Kaliumaneignungsvermögen verschiedener Pflanzenarten. Z Pflanzenernähr Bodenkd 147:276-289

Claassen N, Syring KM, Jungk A (1986) Verification of a mathematical model by simulating potassium uptake from soil. Plant Soil 95:209-220. https://doi.org/10.1007/BF02375073

Courchesne F, Gobran GR (1997) Mineralogical variation of bulk and rhizosphere soils from a Norway spruce stand. Soil Sci Soc Am J 61:1245-1249. https://doi.org/10.2136/sssaj1997. 03615995006100040034x

Drew MC (1975) Comparison of effects of a localized supply of phosphate, nitrate, ammonium and potassium on growth of seminal root system, and the shoot, in barley. New Phytol 75:479-490. JSTOR. www.jstor.org/stable/2431588. Accessed 29 May 2020

Erel R, Bérard A, Capowiez L, Doussan C, Arnal D, Souche G, Gavaland A, Fritz C, Visser EJW, Salvi S, Le Marié C, Hund A, Hinsinger P (2017) Soil type determines how root and rhizosphere traits relate to phosphorus acquisition in field-grown maize genotypes. Plant Soil 412:115-132. https://doi.org/10.1007/s11104-016-3127-3

Gahoonia TS, Care D, Nielsen NE (1997) Root hairs and phosphorus acquisition of wheat and barley cultivars. Plant Soil 191:181-188. https://doi.org/10.1023/A:1004270201418 
Gahoonia TS, Ali O, Sarker A, Nielsen NE, Rahman MM (2006) Genetic variation in root traits and nutrient acquisition of lentil genotypes. J Plant Nutr 29:643-655. https://doi.org/10.1080/ 01904160600564378

Garcia K, Zimmermann SD (2014) The role of mycorrhizal associations in plant potassium nutrition. Front Plant Sci 5:1-9. https://doi.org/10.3389/fpls.2014.00337

Ge ZY, Rubio G, Lynch JP (2000) The importance of root gravitropism for inter-root competition and phosphorus acquisition efficiency: results from a geometric simulation model. Plant Soil 218:159-171. https://doi.org/10.1023/A:1014987710937

Hammond JP, Broadley MR, White PJ, King GJ, Bowen HC, Hayden R, Meacham MC, Mead A, Overs T, Spracklen WP, Greenwood DJ (2009) Shoot yield drives phosphorus use efficiency in Brassica oleracea and correlates with root architecture traits. J Exp Bot 60:1953-1968. https:// doi.org/10.1093/jxb/erp083

Harmsen J (2007) Measuring bioavailability: from a scientific approach to standard methods. J Environ Qual 36:1420-1428. https://doi.org/10.2134/jeq2006.0492

Harmsen J, Rulkens W, Eijsackers H (2005) Bioavailability: concept for understanding or tool for predicting? Land Contam Reclam 13:161-171

Hermans C, Hammond JP, White PJ, Verbruggen N (2006) How do plants respond to nutrient shortage by biomass allocation? Trends Plant Sci 11:610-617. https://doi.org/10.1016/j.tplants. 2006.10.007

Hinsinger P (2004) Nutrient availability and transport in the rhizosphere. In: Goodman RM (ed) Encyclopedia of plant and crop science. Taylor and Francis, London, pp 1094-1097. https://doi.org/10.1201/9780203757604

Hinsinger P (2006) Potassium. In: Lal R (ed) Encyclopedia of soil science, 2nd edn. Taylor and Francis, London. https://doi.org/10.4324/9781315161860

Hinsinger P (2013) Plant-induced changes of soil processes and properties. In: Gregory PJ, Nortcliff S (eds) Soil conditions and plant growth. Wiley-Blackwell, London, pp 323-365. https://doi. org/10.1002/9781118337295

Hinsinger P, Jaillard B (1993) Root-induced release of interlayer potassium and vermiculitization of phlogopite as related to potassium depletion in the rhizosphere of ryegrass. J Soil Sci 44:525-534. https://doi.org/10.1111/j.1365-2389.1993.tb00474.x

Hinsinger P, Jaillard B, Dufey JE (1992) Rapid weathering of a trioctahedral mica by the roots of ryegrass. Soil Sci Soc Am J 56:977-982. https://doi.org/10.2136/sssaj1992. 03615995005600030049x

Hinsinger P, Elsass F, Jaillard B, Robert M (1993) Root-induced irreversible transformation of a trioctahedral mica in the rhizosphere of rape. J Soil Sci 44:535-545. https://doi.org/10.1111/j. 1365-2389.1993.tb00475.x

Hinsinger P, Plassard C, Tang C, Jaillard B (2003) Origins of root-meditated pH changes in the rhizosphere and their responses to environmental constraints: a review. Plant Soil 248:43-59. https://doi.org/10.1023/A:1022371130939

Hinsinger P, Brauman A, Devau N, Gérard F, Jourdan C, Laclau JP, Le Cadre E, Jaillard B, Plassard C (2011) Acquisition of phosphorus and other poorly mobile nutrients by roots. Where do plant nutrition models fail? Plant Soil 348:29-61. https://doi.org/10.1007/s11104-011-0903-y

Hoffland E, Kuyper TW, Wallander H, Plassard C, Gorbushina A, Haselwandter K, Holmström S, Landeweert R, Lundström US, Rosling A, Sen R, Smits MM, Van Hees PAW, Van Breemen N (2004) The role of fungi in weathering. Front Ecol Environ 2:258-264. https://doi.org/10.1890/ 1540-9295(2004)002[0258:TROFIW]2.0.CO;2

Høgh-Jensen H, Pedersen MB (2003) Morphological plasticity by crop plants and their potassium use efficiency. J Plant Nutr 26:969-984. https://doi.org/10.1081/PLN-120020069

Jakobsen I, Abbott LK, Robson AD (1992) External hyphae of vesicular arbuscular mycorrhizal fungi associated with Trifolium subterraneum L. 2. Hyphal transport of ${ }^{32} \mathrm{P}$ over defined distances. New Phytol 120:509-516. www.jstor.org/stable/2557412. Accessed 29 May 2020

Jin K, White PJ, Whalley WR, Shen J, Shi L (2017) Shaping an optimal soil by root-soil interaction. Trends Plant Sci 22:823-829. https://doi.org/10.1016/j.tplants.2017.07.008 
Jobbagy EG, Jackson RB (2001) The distribution of soil nutrients with depth: global patterns and the imprint of plants. Biogeochemistry 53:51-77. https://doi.org/10.1023/A:1010760720215

Jones DL (1998) Organic acids in the rhizosphere - a critical review. Plant Soil 205:25-44. https:// doi.org/10.1023/A:1004356007312

Jones DL, Nguyen C, Finlay RD (2009) Carbon flow in the rhizosphere: carbon trading at the soilroot interface. Plant Soil 321:5-33. https://doi.org/10.1007/s11104-009-9925-0

Jungk A (2001) Root hairs and the acquisition of plant nutrients from soil. J Plant Nutr Soil Sci 164:121-129. https://doi.org/10.1002/1522-2624(200104)164:2\%3C121::AID-JPLN121\% 3E3.0.CO;2-6

Jungk A (2002) Dynamics of nutrient movement at the soil-root interface. In: Waisel Y, Eshel A, Kafkafi U (eds) Plant roots: the hidden half, 3rd edn. CRC Press, Boca Raton, pp 587-616. https://doi.org/10.1201/9780203909423

Kautz T, Amelung W, Ewert F, Gaiser T, Horn R, Jahn R, Javaux M, Kemna A, Kuzyzakov Y, Munch JC, Pätzold S, Peth S, Scherer HW, Schloter M, Schneider H, Vanderborght J, Vetterlein D, Walter A, Wiensenberg GLB, Köpke U (2013) Nutrient acquisition from arable subsoils in temperate climates: a review. Soil Biol Biochem 57:1003-1022. https://doi.org/10. 1016/j.soilbio.2012.09.014

Kodama H, Nelson S, Yang F, Kohyama N (1994) Mineralogy of rhizospheric and non-rhizospheric soils in corn fields. Clay Clay Miner 42:755-763. https://doi.org/10.1346/ CCMN.1994.0420612

Kuchenbuch R, Jungk A (1982) A method for determining concentration profiles at the soil-root interface by thin slicing rhizospheric soil. Plant Soil 68:391-394. https://doi.org/10.1007/ BF02197944

Kuhlmann H (1990) Importance of the subsoil for the K-nutrition of crops. Plant Soil 127:129-136. https://doi.org/10.1007/BF00010845

Kutschera L, Lichtenegger E, Sobotik M (2009) Wurzelatlas der Kulturpflanzen gemäßigter Gebiete mit Arten des Feldgemüsebaues, 7 Band der Wurzelatlas Reihe. DLG, Frankfurt/Main

Lawrence C, Harden J, Maher K (2014) Modeling the influence of organic acids on soil weathering. Geochim Cosmochim Acta 139:487-507. https://doi.org/10.1016/j.gca.2014.05.003

Liu H, White PJ, Li C (2016) Biomass partitioning and rhizosphere responses of maize and faba bean to phosphorus deficiency. Crop Pasture Sci 67:847-856. https://doi.org/10.1071/CP16015

Lynch JP (2007) Roots of the second green revolution. Aust J Bot 55:493-512. https://doi.org/10. 1071/BT06118

Lynch JP (2015) Root phenes that reduce the metabolic costs of soil exploration: opportunities for 21st century agriculture. Plant Cell Environ 38:1775-1784. https://doi.org/10.1111/pce.12451

Mi G, Chen F, Yuan L, Zhang F (2016) Ideotype root system architecture for maize to achieve high yield and resource use efficiency in intensive cropping systems. Adv Agron 139:73-97. https:// doi.org/10.1016/bs.agron.2016.05.002

Moritsuka N, Yanai J, Kosaki T (2004) Possible processes releasing nonexchangeable potassium from the rhizosphere of maize. Plant Soil 258:261-268. https://doi.org/10.1023/B:PLSO. $0000016556.79278 .7 \mathrm{f}$

Niebes JF, Hinsinger P, Jaillard B, Dufey JE (1993) Release of nonexchangeable potassium from different size fractions of two highly K-fertilized soils in the rhizosphere of rape (Brassica napus cv Drakkar). Plant Soil 155:403-406. https://doi.org/10.1007/BF00025068

Obrycki JF, Kovar JL, Karlen DL (2018) Subsoil potassium in Central Iowa soils: status and future challenges. Agrosyst Geosci Environ 1:1-8. https://doi.org/10.2134/age2018.07.0018

Pagès L (2011) Links between root developmental traits and foraging performance. Plant Cell Environ 34:1749-1760. https://doi.org/10.1111/j.1365-3040.2011.02371.x

Philippot L, Raaijmakers JM, Lemanceau P, Van Der Putten WH (2013) Going back to the roots: the microbial ecology of the rhizosphere. Nat Rev Microbiol 11:789-799. https://doi.org/10. 1038/nrmicro3109

Pradier C, Hinsinger P, Laclau JP, Pouillet JP, Guerrini IA, Goncalves JLM, Asensio V, AbreuJunior CH, Jourdan C (2017) Rainfall reduction impacts rhizosphere biogeochemistry in 
eucalypts grown in a deep Ferralsol in Brazil. Plant Soil 414:339-354. https://doi.org/10.1007/ s11104-016-3107-7

Razzaghe MK, Robert M (1979) Géochimie des éléments majeurs des micas en milieu organique: mécanismes de l'altération des silicates. Ann Agron 30:493-512

Rengel Z (1993) Mechanistic simulation models of nutrient uptake: a review. Plant Soil 152:161-173. https://doi.org/10.1007/BF00029086

Robert M, Berthelin J (1986) Role of biological and biochemical factors in soil mineral weathering. In: Huang PM, Schnitzer M (eds) Interactions of soil minerals with natural organics and microbes, Spec Pub 17. Soil Science Society of America, Madison, pp 453-495. https://doi. org/10.2136/sssaspecpub17.c12

Römheld V (1986) pH-Veränderungen in der Rhizosphäre verschiedener Kulturpflanzenarten in Abhängigkeit vom Nährstoffangebot. Potash Rev 55:1-8

Ryan PR, Tyerman SD, Sasaki T, Furuichi T, Yamamoto Y, Zhang WH, Delhaize E (2011) The identification of aluminium-resistance genes provides opportunities for enhancing crop production on acid soils. J Exp Bot 62:9-20. https://doi.org/10.1093/jxb/erq272

Samal D, Kovar JL, Steingrobe B, Sadana US, Bhadoria PS, Claassen N (2010) Potassium uptake efficiency and dynamics in the rhizosphere of maize (Zea mays L.), wheat (Triticum aestivum L.), and sugar beet (Beta vulgaris L.) evaluated with a mechanistic model. Plant Soil 332:105-121. https://doi.org/10.1007/s11104-009-0277-6

Silberbush M, Barber SA (1983) Sensitivity analysis of parameters used in simulating K uptake with a mechanistic mathematical model. Agron J 75:851-854. https://doi.org/10.2134/ agronj1983.00021962007500060002x

Song SK, Huang PM (1988) Dynamics of potassium release from potassium-bearing minerals as influenced by oxalic and citric acids. Soil Sci Soc Am J 52:383-390. https://doi.org/10.2136/ sssaj1988.03615995005200020015x

Sparks DL (1987) Potassium dynamics in soils. Adv Soil Sci 6:1-63. https://doi.org/10.1007/9781-4612-4682-4_1

Sparks DL, Huang PM (1985) Physical chemistry of soil potassium. In: Munson RD (ed) Potassium in agriculture. Am Soc Agron, Madison, pp 201-276. https://doi.org/10.2134/1985. potassium.c 9

Springob G, Richter J (1998) Measuring interlayer potassium release rates from soil materials. II. A percolation procedure to study the influence of the variable 'solute' $\mathrm{K}$ in the $<1 \ldots 10 \mu \mathrm{M}$ range. J Plant Nutr Soil Sci 161:323-329. https://doi.org/10.1002/jpln.1998.3581610321

Taylor LL, Leake JR, Quirk J, Hardy K, Banwarts SA, Beerling DJ (2009) Biological weathering and the long-term carbon cycle: integrating mycorrhizal evolution and function into the current paradigm. Geobiology 7:171-191. https://doi.org/10.1111/j.1472-4669.2009.00194.x

Thomas CL, Graham NS, Hayden R, Meacham MC, Neugebauer K, Nightingale M, Dupuy LX, Hammond JP, White PJ, Broadley MR (2016) High-throughput phenotyping (HTP) identifies seedling root traits linked to variation in seed yield and nutrient capture in field-grown oilseed rape (Brassica napus L.). Ann Bot - London 118:655-665. https://doi.org/10.1093/aob/ mow046

Thonar C, Schnepf A, Frossard E, Roose T, Jansa J (2011) Traits related to differences in function among three arbuscular mycorrhizal fungi. Plant Soil 339:231-245. https://doi.org/10.1007/ s11104-010-0571-3

Thorup-Kristensen K, Halberg N, Nicolaisen M, Olesen JE, Crews TE, Hinsinger P, Kirkegaard J, Pierret A, Dresbøll DB (2020) Digging deeper for agricultural resources, the value of deep rooting. Trends Plant Sci 25:406-417. https://doi.org/10.1016/j.tplants.2019.12.007

Tinker PB, Nye PH (2000) Solute movement in the rhizosphere. Oxford University Press, New York

Vacheron J, Desbrosses G, Bouffaud ML, Touraine B, Moënne-Loccoz Y, Muller D, Legendre L, Wisniewski-Dyé F, Prigent-Combaret C (2013) Plant growth-promoting rhizobacteria and root system functioning. Front Plant Sci 4. https://doi.org/10.3389/fpls.2013.00356 
Walker JM, Barber SA (1962) Absorption of potassium and rubidium from the soil by corn roots. Plant Soil 17:243-259. https://doi.org/10.1007/BF01376227

White PJ (2013) Improving potassium acquisition and utilisation by crop plants. J Plant Nutr Soil Sci 176:305-316. https://doi.org/10.1002/jpln.201200121

White PJ, Karley AJ (2010) Potassium. In: Hell R, Mendel R-R (eds) Cell biology of metals and nutrients. Springer, Berlin, pp 199-224

White PJ, George TS, Gregory PJ, Bengough AG, Hallett PD, Mckenzie BM (2013) Matching roots to their environment. Ann Bot - Lond 112:207-222. https://doi.org/10.1093/aob/mct123

White PJ, Kawachi T, Thompson JA, Wright G, Dupuy LX (2016) Minimizing the treatments required to determine the responses of different crop genotypes to potassium supply. Commun Soil Sci Plant Anal 47:104-111. https://doi.org/10.1080/00103624.2016.1232103

Wishart J, George TS, Brown LK, Ramsay G, Bradshaw JE, White PJ, Gregory PJ (2013) Measuring variation in potato roots in both field and glasshouse: the search for useful yield predictors and a simple screen for root traits. Plant Soil 368:231-249. https://doi.org/10.1007/ s11104-012-1483-1

Wissuwa M (2003) How do plants achieve tolerance to phosphorus deficiency? Small causes with big effects. Plant Physiol 133:1947-1958. www.jstor.org/stable/4281510. Accessed 29 May 2020

Witter E, Johansson G (2001) Potassium uptake from the subsoil by green manure crops. Biol Agric Hortic 19:127-141. https://doi.org/10.1080/01448765.2001.9754917

Yan X, Liao H, Beebe SE, Blair MW, Lynch JP (2004) QTL mapping of root hair and acid exudation traits and their relationship to phosphorus uptake in common bean. Plant Soil 265:17-29. https://doi.org/10.1007/s11104-005-0693-1

York LM, Galindo-Castaneda T, Schussler JR, Lynch JP (2015) Evolution of US maize (Zea mays L.) root architectural and anatomical phenes over the past 100 years corresponds to increased tolerance of nitrogen stress. J Exp Bot 66:2347-2358. https://doi.org/10.1093/jxb/erv074

Open Access This chapter is licensed under the terms of the Creative Commons Attribution 4.0 International License (http://creativecommons.org/licenses/by/4.0/), which permits use, sharing, adaptation, distribution and reproduction in any medium or format, as long as you give appropriate credit to the original author(s) and the source, provide a link to the Creative Commons license and indicate if changes were made.

The images or other third party material in this chapter are included in the chapter's Creative Commons license, unless indicated otherwise in a credit line to the material. If material is not included in the chapter's Creative Commons license and your intended use is not permitted by statutory regulation or exceeds the permitted use, you will need to obtain permission directly from the copyright holder.

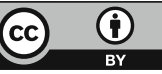

